УДК 347.73

DOI https://doi.org/10.32837/pyuv.v0i3(32).604

\author{
К.В.Солодан \\ orcid.org/0000-0002-2872-5332 \\ аспірант кафедри публічного права \\ Чернівецького національного університету імені Юрія Федьковича
}

\title{
ПРАВОВЕ РЕГУЛЮВАННЯ ОПОДАТКУВАННЯ ЕЛЕКТРОННОЇ КОМЕРЦІЇ У СПОЛУЧЕНИХ ШТАТАХ АМЕРИКИ: АНАЛІЗ КЛЮЧОВИХ ПРЕЦЕДЕНТІВ
}

Постановка проблеми. Останні десятиліття для всього світу виявилися часом радикальних змін. Зміни стосувалися всіх сфер суспільного життя: економіки і політики, науки і техніки, культури і мистецтва. Однією з основних змін останнього часу є поширення мережі Інтернет та, як наслідок, виникнення і масове поширення такого специфічного виду підприємницької діяльності, як електронна торгівля. Нині більшість компаній незалежно від їхніх масштабів і форм власності, від невеликих фірм до великих корпорацій, приділяють значну увагу продажу своїх товарів і послуг у мережі Інтернет, що дозволяє їм пропонувати більш широкий асортимент для споживачів, з одного боку, і поліпшити якість обслуговування покупців за менших витрат, з іншого боку [2, с. 3].

Електронна торгівля формує принципово новий «віртуальний» канал збуту товарів і послуг, що спричиняє зміну традиційних способів ведення підприємницької діяльності. Натепер суб'єктом електронного підприємництва інформація, послуги та цифрові товари можуть бути реалізовані в режимі онлайн: тобто весь процес продажу, оплата також, відбувається за допомогою мережі Інтернет. Необхідно зазначити, що створення цієї глобальної інформаційної мережі стало результатом глобалізації світової економіки i, незважаючи на те, що нині користувачами Інтернету є і громадяни, і суб'єкти господарювання (підприємства, індивідуальні підприємці, фінансово-кредитні установи тощо), організовувалася вона саме для досягнення тих чи інших економічних цілей. Нині в усьому світі кількість онлайнових комерційних операцій стрімко зростає [6, с. 5].

Такий стрімкий розвиток електронної комерції потребує адекватного правового регулювання, зокрема правового регулювання оподаткування такого виду діяльності. Адже неналежне правове регулювання оподаткування електронної комерції сприяє уникненню від оподаткування суб'єктів такої господарської діяльності, що має наслідком неналежне забезпечення права людини на податки [3]. Така проблема характерна для більшості держав і потребує вирішення, зважаючи на досвід різних юрисдикцій. На нашу думку, для визначення необхідного шляху правового регулювання оподаткування електронної комерції, необхідно проаналізувати досвід Сполучених Штатів Америки (далі - США) як держави, що першою почала здійснювати кроки для вирішення цієї проблеми.

Стан дослідження. Питання правового регулювання електронної комерції досліджували І.Б.Бєлік, Н.М. Борейко, Н.М.Васильєва,О.М.Гаркушенко, Н.В. Козинець, Е. Міллер, М.М. Феітоса, Л.Я. Фролова й інші. Проте залишається необхідним дослідити ключові прецеденти США, що стали основою для подальшого правового регулювання оподаткування електронної комерції.

Метою дослідження є визначення особливостей правового регулювання оподаткування електронної комерції у США. Конкретним його завданням є аналіз ключових американський прецедентів, що є джерелами права з питання оподаткування електронної комерції у США.

Виклад основного матеріалу. У США через труднощі з оподаткуванням електронної комерції щорічно втрачаються до 23 млрд дол. надходжень податку на продажі [10, с. 2]. Податок на продажі, який використовується переважно у США, за Конституцією може стягуватися лише якщо і продавець, і покупець фізично присутні в тому самому штаті. Фізична присутність означає, що покупець або продавець зареєстровані будь-яким чином у штаті, мають там власність або представництво. Деталі того, що мається на увазі під терміном «фізична присутність», від штату до штату можуть різнитися [8, с. 6]. Водночас не має різниці, яку покупку здійснює покупець: у матеріальній або нематеріальній формі. Проте застосовуватиметься податок лише до кінцевих споживачів або і до підприємств - залежить від законодавства конкретного штату [8, с. 6]. Така ситуація призвела до того, що великі підприємства, які здійснюють операції 3 електронної комерції (на кшталт Amazon, Google), мали можливість отримувати додаткові конкурентні переваги над «фізичними» магазинами (тобто такими, що мають власні торгові зали, де виставляється продукція) і онлайн-магазинами, розташованими в тому самому штаті, що і їхні основні покупці. Це відбувалося через те, що фактично до 2012 р. Amazon та Google мали фізичну присутність в 1-5 штатах, де вони і повинні були сплачувати податок на продажі. У решті штатів 
таких зобов'язань вони не мали, а отже, забезпечували собі конкурентні переваги [4].

Як відомо, у податковій системі США відсутній податок на додану вартість, але застосовується податок із продажів (sales tax). Нині він є основним непрямим податком, що стягується штатами та місцевими територіальними утвореннями з електронної комерції. Крім того, операції електронної комерції оподатковуються податком на використання (use tax) [5]. Різниця між ними полягає в тому, що ПДВ збирається через поетапний процес, а податок із продажу або використання нараховується лише один раз у кінцевій точці продажу [9].

Податок із продажів повинен бути сплачений iз роздрібних продажів в юрисдикції штату, резидентом якого є покупець, водночас податковим агентом виступає продавець: податок включається ним до вартості товару, а потім перераховується податковим органам. Правила оподаткування кожен штат встановлює самостійно, а це значить, що ставки, порядок сплати та звітності в кожному штаті і навіть в кожному місті можуть відрізнятися (за даними Національної федерації роздрібної торгівлі США, у Сполучених Штатах існує приблизно 7,5 тис. юрисдикцій із цього податку). Ставки податку із продажів варіюються від 0,125 до 8\% . Необхідно зазначити, що податок із продажів зазвичай стягується під час реалізації товарів і послуг усередині штату, тобто продажі за межі штату, зокрема й в Інтернеті, під оподаткування цим податком не підпадають. Для усунення конкурентної переваги компаній, що займаються електронною торгівлею з іншими юрисдикціями, більшість штатів США і місцевих територіальних утворень ввели податок на використання, який повинен сплачуватися вже не продавцем, а покупцем, якщо останній набуває товар або послугу у продавця-нерезидента. Податок на використання зазвичай сплачується за тими ж ставками, що і податок із продажів, який підлягав би сплаті, якби покупець придбав товар або послугу на території штату, де він є резидентом. Отже, електронна комерція може викликати зниження надходжень непрямих податків у тих штатах, де зосереджені переважно продавці, а не покупці цифрових товарів і електронних послуг [1;9].

Незважаючи на таку автономію та конкуренцію між штатами, федеральний уряд ухвалив Закон про свободу від податку в Інтернеті [12] 3 метою стимулювання трансакцій електронної комерції з початковим періодом у три роки, який підлягав послідовному продовженню. Закон про свободу від податку в Інтернеті має на меті уникнути введення нових податків, але не звільняє продажі з Інтернету, які надалі будуть здійснюватись на тій же основі, що і фізичні продажі. 3 іншого боку, через складність податкової системи деякі штати намагаються стандартизувати правила щодо податку із продажу через раціоналізовану угоду з податку на продаж. Цей проєкт має на меті досягти спрощення податків шляхом єдиного визначення податків, спрощення та більш рівномірного оподаткування та збору, спрощення податкових ставок та державного фінансування адміністративних витрат [9].

У цьому контексті необхідно розуміти значення комерційного застереження (commerce clause), метою якого є збереження вільного потоку міжштатної торгівлі, і застереження про належну правову процедуру (due process clause), яка має на меті захистити громадян від довільного здійснення державних повноважень, не обмежених ні принципами, встановленими приватним правом, ні розподільним правосуддям. Тлумачення комерційного застереження, здійснене Верховним Судом, полягало в тому, що коли штат захоче ввести податок із продажу, необхідно, щоби продаж мав істотний зв'язок зі штатом (nexus). Як у "Quill Corp. v. North Dakota" [16], так і в "National Bellas Hess v. Illinois Department of Revenue" [14] цей зв'язок розумівся як фізична присутність у штаті. Проте в Південній Дакоті проти Wayfair Inc. ("South Dakota v. Wayfair Inc.") [17], також названій «справою тисячоліття», Верховний Суд скасував і Квілл, і Північну Дакоту, і заявив, що правило про фізичну присутність є неправильним. Навіть більше, хоча Верховний Суд відхилив перегляд, як “Amazon.com, LLC v. New York State Department of Taxation and Finance" [7], так i "Overstock.com, Inc. v. New York State Department of Taxation and Finance" [15], у таких провідних справах рішення Апеляційного суду Нью-Йорка переважали, вирішив, що підприємства повинні сплачувати податок із продажу в Нью-Йорку, незважаючи на відсутність фізичної присутності у штаті та припускаючи, що гіпотетично не порушено комерційне застереження та застереження про належну правову процедуру.

На нашу думку, необхідно розглянути ці прецеденти детальніше. Як суд загального права Верховний Суд США щороку розглядає дуже мало справ, порівняно із судами цивільного права. Якщо перший передбачає, що Верховний Суд повинен діяти в невеликій кількості справ, останній зазвичай працює протилежно до загальних судових інстанцій, розуміє, що для досягнення однорідності суд повинен мати можливість переглядати велику кількість рішень. Тому це два різні маршрути з однією метою - досягнення однорідності. Однак перший може розглядатися як «академічний комітет», який обмежує свою участь питаннями, що викликають широкий інтерес, а другий функціонує як «фабрика», розглядає велику кількість справ, хоча і поверхнево. Крім того, згідно із загальним правом сторони не мають права розгляду своїх клопотань Верхов- 
ним Судом, який має право на вибір того, що буде судити. Тому важливо зазначити, що роль Верховного Суду в судочинстві з питань оподаткування протягом багатьох років не була однаковою [13]. Першим прецедентом щодо цього став $\mathrm{Na}$ tional Bellas Hess, Inc. проти Департаменту доходів штату Іллінойс (“National Bellas Hess, Inc. v. Department of Revenue of Illinois") [14], який був винесений 8 травня 1967 p. National Bellas Hess був будинком замовлень з основним місцем своєї діяльності у штаті Міссурі, який не мав фірм в Іллінойсі і не розміщував реклами на радіо, телебаченні або в будь-яких журналах штату. Проте він надсилав каталоги двічі на рік клієнтам по всій території США, в Іллінойс також. Замовлення на товари були відправлені на завод підприємства, а товари відправлялися споживачам поштою або загальним перевізником. Відповідно до законодавства штату Іллінойс, Bellas Hess належав до роздрібної торгівлі, зберігав своє місцезнаходження у штаті і повинен був стягувати податок на використання Іллінойсу.

Верховний суд штату Іллінойс визнав оподаткування штату дійсним, що призвело до того, що Bellas Hess звернулися з апеляцією до Верховного Суду США, стверджували наявність порушення застереження про належну правову процедуру та неконституційне обмеження міжштатної комерції. Верховний Суд у відповідь ухвалив, що Конституція вимагає певного зв'язку, деякого мінімального зв'язку між штатом та особою, майном чи трансакцією, яку він прагне оподатковувати $<. .>$ Але Суд ніколи не вважав, що штат може накладати обов'язок збирання податку на використання і його сплати на продавця, чий єдиний зв'язок із клієнтами у штаті здійснюється звичайним перевізником або поштою у США.

Верховний Суд вирішив, що комерційне застереження має основну мету - забезпечити національну економіку, вільну від невиправданих місцевих обмежень. На додаток до цього Верховний Суд заявив, якщо Іллінойс міг би встановити такі обмеження на торгівлю, то будь-який інший штат, а також будь-яке інше національне політичне утворення також могло б це зробити, створити зобов'язання на користь місцевих юрисдикцій, але без легітимності. Нарешті, було зазначено, що National Bellas Hess уже має зобов' язання стягувати податок із продажу в Алабамі, Канзасі та Міссісіпі, оскільки там є його магазини. 3 іншого боку, уважалося, що одинадцять інших штатів, окрім штату Іллінойс, створили податкові зобов'язання, аналогічні оскаржуваному законодавству [14].

У відповідь на рішення Верховного Суду Алабами Верховний Суд США зазначив, що податок із продажу, який у багатьох штатах доповнюється податком на використання, нараховувався в той час у 2300 різних місцях. Отже, якби супере- чливе законодавство було збережене, наслідком цього було б те, що постачальники повинні були б адмініструвати правила, що відрізняються від одного штату до іншого, що вимагало б знань про віддалені та невизначені правила на рівні точності, необхідної для системного адміністрування податків [13].

Друга провідна справа - "Quill Corp. проти Північної Дакоти” (“Quill Corp. v. North Dakota”) [16] від 26 травня $1992 \mathrm{p}$. Quill - це товариство штату Делавер з офісами та складами в Іллінойсі, Каліфорнії та Джорджії. Жооден із його співробітників не працював і не проживав у Північній Дакоті, i в цьому штаті воно мало незначну кількість власності. Quill продавало офісну техніку й інвентар, рекламувало свій бізнес через каталоги, газети та телефонні дзвінки. Деякі продажі здійснювались споживачам у Північній Дакоті, які отримували свої замовлення поштою та перевізниками. Законодавство Північної Дакоти передбачало, що будь-який роздрібний продавець, який має місцерозташування бізнесу у штаті, повинен стягувати податок зі споживача та перераховувати його штату. Однак із 1987 р. в законодавство було внесено зміни, які передбачають, що термін «роздрібний торговець» охоплює будь-яку особу, яка намагається регулювати або систематично залучати споживчі ринки в державі. Водночас було визначено, що фраза «регулярне або систематичне залучення ринку» означає три чи більше рекламних оголошень протягом дванадцяти місяців. Відповідно до цього законодавства, Quill почало обкладатися податками в Північній Дакоті, хоча товариство не мало ні власності, ні робочих місць у штаті. Верховний Суд Північної Дакоти вирішив, що зміни як в економіці, так і в законі зробили недоцільним дотримуватись Bellas Hess, дійшов висновку про те, що фізична присутність більше не потрібна для дотримання комерційного застереження та встановлення зв'язку, необхідного для застереження про належну процедуру. Проте Верховний Суд США скасував рішення Верховного Суду штату i заявив, що Bellas Hess усе ще треба керуватися. Навіть більше, Верховний Суд США вирішив, що, незважаючи на нові рішення після Bellas Hess, y яких була прийнята інша лінія розмежування від так званої фізичної присутності, це було зроблено стосовно інших податків, крім податку із продажу та використання. У зв'язку із цим продовжуватиме діяти прецедент, підписаний у справі Bellas Hess. Верховний Суд США зазначив, що Конгрес може змінити це тлумачення комерційного застереження, скасувати Bellas Hess, оскільки він має повноваження це робити [16].

Третіми провідними справами є "Amazon.com, LLC проти Департаменту оподаткування та фінансів штату Нью-Йорк” (“Amazon.com, LLC v. New York State Department of Taxation and Finance") 
[7] та "Overstock.com, Inc. проти Департаменту оподаткування та фінансів штату Нью-Йорк ("Overstock.com, Inc. v. New York State Department of Taxation and Finance") [15] від 28 березня 2013 р. Ці випадки зумовлені зміною законодавства Нью-Йорку, відомого також як інтернет-податок, який вніс зміни до Закону про податки у штаті Нью-Йорк і встановив, що податок на продаж та використання буде покладений на сторонніх (нерезидентів) продавців, до яких мешканці, які перебувають у штаті Нью-Йорк, переходять за торговими посиланнями або банерами на їхніх вебсайтах. Законодавство визнало докази протилежного. Як і Amazon, Overstock ставила під сумнів згадану поправку законодавства перед Апеляційним судом, оскільки обидва підприємства не мали співробітників чи офісів у Нью-Йорку, а продукція, що купувалась в Інтернеті, надсилалась клієнтам безпосередньо електронною поштою або звичайним транспортом [13].

Обидві компанії розробили програму асоціацій з використанням третіх сторін, розташованих по всьому світу, які розміщують на власних сайтах посилання, які, у разі натискання на них, дозволяють переходити на сайти закупівель цих компаній. Партнери отримують комісійні із продажів, які складаються з відсотка від прибутку, отриманого $з$ покупок за посиланнями або банерами на ïхніх сайтах. Варто зазначити, що між асоційованими компаніями й Amazon або Overstock не існувало залежності або трудових відносин.

Amazon i Overstock стверджували, що законодавство Нью-Йорку порушило комерційне застереження та застереження про належну процедуру, коли встановило оподаткування для суб'єктів, які перебувають поза штатом і не мають істотного зв'язку зі штатом Нью-Йорк. Навіть більше, компанії стверджували, що законодавство створюе презумпцію, яка буде незаперечною, мотивували це тим, що вкрай важко буде довести, що жодна з філій не заохочує клієнтів стати споживачами в інтересах продавця $[7 ; 15]$.

Однак Верховний Суд Нью-Йорку відхилив позовні вимоги Amazon i Overstock та підтримав захист, поданий Департаментом оподаткування та фінансів, визнав Закон Нью-Йорку конституційним. Хоча Суд стверджує, що наявна паралель між поштовим та інтернет-бізнесом, оскільки обидві ділові дії здійснюються без потреби фізичної присутності, в інтернет-торгівлі є деякі особливості.

Було встановлено, що багато вебсайтів спрямовані переважно на місцеві аудиторії, як-от радіостанції, релігійні установи та коледжі, так що фізична присутність власника сайту стає відповідною до аналізу комерційного застереження. Отже, угоди між Amazon та його філіями, які встановлюють посилання для продажу для цієї компанії у штаті Нью-
Йорк, становлять істотний зв'язок, що вимагається комерційним застереженням, що надає Amazon справжню можливість продажів у штаті. 3 іншого боку, що стосується аргументу про те, що презумпція буде незаперечною, Верховний Суд Нью-Йорку відхилив його та зазначив, що Державний департамент фінансів розробив метод (контрактна заборона та щорічна сертифікація), за допомогою якого можна спростувати презумпцію. Був розбіжний голос, який розумів, що розміщення посилань на вебсайтах резидентів Нью-Йорку полягало у простій рекламі, i оснастити їх агентами із продажу неможливо. Однак більшістю 4-1 рішенням суду Нью-Йорку було те, що законодавство штату відповідає як Комерційному застереженню, так і Застереженню про належну правову процедуру.

Згодом були подані апеляційні скарги до Верховного Суду США. Однак Верховний Суд не задовольнив апеляційну скаргу. Насправді, правило 10 Регламенту Верховного Суду виражається в тому сенсі, що навіть у гіпотезах, описаних у Правилі 10, дискреція Верховного Суду для гарантії апеляції не скасовується. Тому у справі Amazon, незважаючи на рішення апеляційного суду Нью-Йорку, суперечливе щодо розуміння інших судів штату, Верховний Суд мав достатню свободу відхиляти апеляційну скаргу Amazon, як це зробив [13].

Четвертий і останній прецедент також відомий як "справа тисячоліття» через вплив на оподаткування продажів електронної комерції. У справі «Південна Дакота проти Wayfair Inc." ("South Dakota v. Wayfair Inc.”) [17] від 21 червня 2018 p. Верховний Суд скасував Bellas Hess [14] і Quill [16] і вирішив, що вимога фізичної присутності $€$ неправильним тлумаченням Комерційного застереження. У 2016 р. Південна Дакота запровадила акт, згідно з яким продавці-нерезиденти повинні за певних умов збирати та перераховувати податок із продажу, як ніби продавець мав фізичну присутність у штаті, тому що законодавчий орган встановив, що неможливість збирати податок із продажу та податок на використання віддалених продавців розмивала базу податку із продажів і спричиняла збитки, оскільки в Південній Дакоті немає податку на прибуток. Щоб отримати визнання конституційності закону, Південна Дакота подала деклараційну судову дію та заборону. Верховний Суд Південної Дакоти заявив, що Quill не було скасовано і він залишається прецедентом у питанні комерційного застереження [11].

Проте Верховний Суд США визнав, що Інтернет змінив динаміку економіки, та вирішив, що податки штатів діють доти, доки вони «(1) застосовуються до діяльності, яка має істотний зв'язок зі штатом оподаткування; (2) є справедливими; (3) не дискримінують міжштатну торгівлю; (4) стосуються послуг, які надає штат». 
На додаток до цього Верховний Суд зазначив, що правило фізичної присутності віддає перевагу стороннім (нерезидентам) продавцям, що призводить до спотворення ринку та створює нерівність між роздрібними інтернет-торговцями та їхніми конкурентами, які збирають податки із продажу штатів. Відповідно до цих аргументів Верховний Суд вирішив, що чекати заходів від Конгресу не потрібно [17].

"South Dakota v. Wayfair Inc." відіграватиме важливу роль в оподаткуванні не тільки для американських підприємств, але і для підприємств, які не є американськими, які не мають фізичної присутності у США, але продають там продукти, 3 огляду на те, що вони можуть бути зобов'язані збирати та переказувати податок із продажу та податок із використання різних штатів, а у США немає єдиного вікна (one stop shop), як у європейських країнах $[11 ; 13]$.

Висновки. Отже, у результаті проведеного аналізу ключових прецедентів США бачимо, як еволюціонує правове регулювання оподаткування електронної комерції у Сполучених Штатах. Справа "South Dakota v. Wayfair Inc." запроваджує правила, що відповідають вимогам часу. Адже технології надзвичайно швидко крокують уперед, дистанційна торгівля стає буденною та значно переважає над традиційною, тому належне оподаткування суб'єктів електронної комерції є нагальною вимогою часу, щоби забезпечити справедливе та рівноправне оподаткування суб'єктів господарювання різного масштабу i, як наслідок, забезпечити дотримання права людини на податки. Оскільки правила оподаткування, що спираються суто на фізичну присутність у певному штаті, надають суттєві переваги технологічним гігантам, які здійснюють продажі в різних штатах без фізичної присутності. Новий підхід є справедливим для великого бізнесу і водночас захищає малий бізнес. Тому справа "South Dakota v. Wayfair Inc." матиме значний позитивний вплив на штати та їхніх громадян.

\section{Jimepamypa}

1. Бєлік І.Б. Міжнародно-правовий досвід оподаткування електронної комерції. Форум права. 2013. № 2. C. 49-54. URL: http://nbuv.gov.ua/UJRN/FP index.htm_2013_2_10.

2. Васильева Н.М. Правовое регулирование налогообложения электронной коммерции : автореф. дис. ... канд. юрид. наук: 12.00.14. Москва, 2007. 27 с.

3. Гаврилюк Р.О. Природа податкового права: антропосоціокультурний підхід : монографія. Чернівці : Чернівецький нац. ун-т, 2014. $636 \mathrm{c.}$

4. Гаркушенко О.М. Податки на продажі в цифрову епоху: уроки для України : науково-аналітична доповідь. НАН України, Ін-т економіки пром-сті. Київ, 2018. 42 с. URL: https://iie.org.ua/wp-content/ uploads/2019/02/Garkushenko_gotov.pdf.

5. Козинец Н.В. Эволюция правового регулирования трансграничной электронной торговли в законодательстве США. Актуальные проблемы российского пра ва. 2015. № 9. URL: https://cyberleninka.ru/article/n/ evolyutsiya-pravovogo-regulirovaniya-transgranichnoyelektronnoy-torgovli-v-zakonodatelstve-ssha.

6. Фролова Л.В. Налогообложение электронной торговли : дис. ... канд. эконом. наук: 08.00.10. Саратов, 2009. $181 \mathrm{c.}$

7. Amazon.com, LLC v. New York State Department of Taxation and Finance. URL: http://www.courts.state.ny.us/Reporter/3dseries/2009/2009_29007.htm.

8. Baugh B., Ben-David I., Park H. Can taxes shape an industry? Evidence from the implementation of the " $\mathrm{Am}$ azon tax". NBER Working Paper 20052. 2018. January. 54 p. URL: http://www.nber.org/papers/w20052.

9. Catherine Chen. Taxation of Digital Goods and Services. URL: https://annualsurveyofamericanlaw.org/ wp-content/uploads/2016/02/70-4 chen.pdf.

10. Taxes, the Internet and the Digital Economy / J. Corkery et al. Revenue Law Journal. 2013. Vol. 23. Iss. 1. Art. 7.

11. Eric C. Miller. Answering the call: South Dakota v. Wayfair, Inc. and a challenge to the physical presence rule. URL: https://www.usd.edu/news/2019/south-dakota-law-review-publishes-first-issue-of-65th-volume.

12. Internet Tax Freedom Act. URL: https://www.congress.gov/108/plaws/publ435/PLAW108publ435.htm.

13. Maurine Morgan P. Feitosa. The taxation of e-commerce in the digital era: common and civil law. RDIET. Brasilia. 2018. V. 13. № 1. P. 356-385. URL: https://bdtd.ucb.br/index.php/RDIET/article/download $/ 10259 / 5996$

14. National Bellas Hess v. Department of Revenue. URL: https://supreme.justia.com/cases/federal/ us $/ 386 / 753 /$.

15. Overstock.com, Inc. v. New York State Department of Taxation and Finance. URL: https://law.justia.com/cases/new-york/court-of-appeals/ 2013/33.html.

16. Quill Corp. v. North Dakota. URL: https://supreme.justia.com/cases/federal/us/504/298/.

17. South Dakota v. Wayfair Inc. URL: https: / / www.supremecourt.gov/opinions / 17pdf/17-494_j4el.pdf.

\section{Анотація}

Солодан $К$. В. Правове регулювання оподаткування електронної комерції у Сполучених Штатах Америки: аналіз ключових прецедентів. - Стаття.

Стаття присвячена особливостям правового регулювання оподаткування електронної комерції у Сполучених Штатах Америки. Зазначено, що поширення мережі Інтернет та масове поширення електронної торгівлі потребує адекватного правового регулювання оподаткування такого виду підприємницької діяльності, щоби запобігти уникненню від оподаткування суб'єктів електронної комерції, тим самим забезпечити належне здійснення права людини на податки. Визначено різницю між податком із продажів та податком на використання. У статті визначено значення комерційного застереження та застереження про належну правову процедуру. Досліджено еволюцію прецедентів, що містять норми, предметом регулювання яких $є$ оподаткування електронної комерції. Проаналізовано судову аргументацію, викладену у ключових судових рішеннях, що стосуються поставленої проблематики: “Amazon.com, LLC v. New York State Department of Taxation and Finance"; "National Bellas Hess v. Department of Revenue"; "Overstock. 
com, Inc. v. New York State Department of Taxation and Finance"; "Quill Corp. v. North Dakota"; "South Dakota v. Wayfair Inc.”. Проаналізовано судове тлумачення «суттєвого зв'язку», необхідного для оподаткування в певному штаті. Вказано, що технології надзвичайно швидко крокують уперед, дистанційна торгівля стає буденною та значно переважає над традиційною, тому належне оподаткування суб'єктів електронної комерції є нагальною вимогою часу, щоби забезпечити справедливе та рівноправне оподаткування суб'єктів господарювання різного масштабу i, як наслідок, забезпечити дотримання права людини на податки. Зроблено висновок, що правило про фізичну присутність є неправильним. Справа "South Dakota v. Wayfair Inc." відповідає вимогам часу, а запроваджене нею правило істотного зв’язку сприятиме справедливому оподаткуванню суб'єктів електронної комерції, захистить суб'єктів малого підприємництва від переважання цифрових гігантів, які здійснюють продажі в багатьох штатах і водночас не мають там жодної фізичної присутності.

Ключові слова: електронна комерція, оподаткування, податок із продажів, податок із використання, фізична присутність.

\section{Summary}

Solodan K. V. Legal regulation of taxation of e-commerce in the USA: analysis of key precedents. - Article.

The article is devoted to the peculiarities of the legal regulation of e-commerce taxation in the United States of America. The researcher states that the widespread use of the Internet and the widespread use of e-commerce require adequate legal regulation of the taxation of this type of business to prevent tax evasion by e-commerce, thereby ensuring the proper exercise of the human right to taxes. Author determines the difference between sales tax and use tax. The article defines the meaning of a commercial clause and a clause on due process. The evolution of precedents containing norms subject to electronic commerce taxation has been studied by the researcher. The court arguments presented in the key court decisions related to the issues are analyzed: "Amazon.com, LLCv. New York State Department of Taxation and Finance"; "National Bellas Hess v. Department of Revenue"; "Overstock.com, Inc. v. New York State Department of Taxation and Finance"; "Quill Corp. v. North Dakota"; "South Dakota v. Wayfair Inc.". The judicial interpretation of the "essential connection" required for taxation in a particular state is analyzed. It is concluded that the rule of physical presence is incorrect. Case of South Dakota v. Wayfair Inc. meets the requirements of the times, and its "essential communication" rule will promote fair taxation of e-commerce entities, protect small businesses from the dominance of digital giants that sell in many states without a physical presence. The conclusion is made that technology is advancing extremely fast, distance trade is becoming commonplace and far outweighing traditional ones, so proper taxation of e-commerce is an urgent need to ensure fair and equitable taxation of businesses of all sizes and, as a result, human right to taxes.

Key words: electronic commerce, taxation, commercial clause, clause on due process, nexus. 